$\begin{array}{r}\text { Bartın Üniversitesi } \\ \text { Eğitim Fakültesi Dergisi }\end{array}$
Cilt 6, Sayı 3, s. 1134-1152, Ekim 2017
BARTIN - TÜRKIYE $\begin{aligned} & \text { Bartin University } \\ & \text { Journal of Faculty of Education } \\ & \text { Volume 6, Issue 3, p. 1134-1152, October } 2017 \\ & \text { BARTIN - TURKEY }\end{aligned}$

Doi: 10.14686/buefad.290859

\title{
Öğretmenlerin Gözünden Eğitimde Kalite Sorunsalı
}

Yasemin BÜYÜKŞAHIN, Arş. Gör. , Bartın Üniversitesi Eğitim Fakültesi, ybuyuksahin@bartin.edu.tr ORCID: http://orcid.org/0000-0002-5771-2063

Ali Ekber ŞAHIN, Prof. Dr. Hacettepe Üniversitesi Eğitim Fakültesi, alisahin@hacettepe.edu.tr

Öz: Bir toplumun refah seviyesini artırma için alınacak yolun en önemli adımı eğitim sistemini güçlendirmektir. Bu da eğitimde kalite yönetimi ile mümkündür. Ülkemizde kalite için "Toplam Kalite Yönetimi" başlığında uygulamalara yer verilmektedir. Çalışmanın amacı bu uygulamaların işlevselliğini öğretmenlerle birlikte yordama ve eğitimde kalite sorunsalını ortaya koymaktır. Bu amaçla derinlemesine çalışabilmek için nitel yöntemlerden yarı yapılandırılmış görüşme tekniği tercih edilmiş ve gönüllü 14 öğretmenin görüşlerine başvurulmuştur. Sonuç olarak öğretmenlerimiz öğretmen seçiminde yeterli düzeyde ayırt edici olamadığımızı, öğretmen eğitiminde saha için gerekli tecrübeyi öğretmen adayına kazandıramadığımızı belirtmektedirler. Kaliteli eğitim için öğretmenin mesleğini ve öğrencilerini sevmesi sosyal ve sabırlı bir rehber olması gerektiğini vurgulamaktadırlar. Kaliteli okul için fiziki ve mali şartların iyileştirilmesi gerektiğini, kaliteli eğitim için de velilerin bilinçlendirilmesi gerektiğini düşünmektedirler. Çalışma grubundaki öğretmenlerin çoğunluğu ülkemizde eğitimde uygulanan toplam kalite yönetimi uygulamalarının kâğıt üzerinde yapıldığını ve bu tarz uygulamaların herhangi bir fayda sağlamayacağına inandıklarını dile getirmişlerdir. Çalışma sonuçlarına göre kalite yönetimi planlayıcılarına okullarda daha gerçekçi uygulama örneklerinin tanıtılması önerilebilir. Eğitim kalitesinin paydaşları ve yapabilecekleri uygulamalı olarak kendilerine aktarılabilir. İyi uygulamaların tanıtımı yaygınlaştırılarak gönüllü olan paydaşlara teşvikler ayrılması önerilebilir.

Anahtar Kelimeler: eğitim, kalite, kaliteli okul, öğretmen görüşleri, toplam kalite yönetimi

\section{Quality Problematic in Education from Teachers' View Point}

\begin{abstract}
The most important step towards increasing the level of welfare of a community is to strengthen the education system. This is possible with quality management in education. For the quality in our country, there is an application called "Total Quality Management". The aim of the study is to determine the functioning of these applications together with the teachers and to reveal the quality problem in education. For this purpose, a semistructured interview technique was chosen from qualitative methods in order to study in depth and the opinions of 14 volunteer teachers were applied. As a result, our teachers point out that we are not able to distinguish adequately in the selection of teachers in the field of teacher education. For quality education, they emphasizes that the teacher must be social, patient guide and love the profession and the students. They think that physical and financial conditions should be improved for quality school, and parents should be educated for quality education. In the study group the majority of the teachers stated that the total quality management practices do not benefit and made on paper in our country. According to the results of the study, it may be suggested to introduce more realistic application examples to quality management planners. The quality of education can be transferred to the stakeholders and the practitioners themselves. It may be advisable to provide incentivesfor volunteer stakeholders by disseminating good practices.
\end{abstract}

Key Words: education, quality, quality school, teacher opinions, total quality management 


\section{GíRiş}

Kalite üretimde beklentilerini yanıtlama düzeyi, müşterilerin ürün ya da hizmet için hissettiği doyumu, memnuniyet düzeyi olarak tanımlanmakta, müşterilerce istenen şeyin sağlanması olarak ifade edilmektedir (Kaufman ve Zahn,1993'den Akt: Şahin,2009).

Kalitenin artırılması için kurum ve kuruluşlarda toplam kalite yönetimi uygulanmaktadır. Eğitimde kullanılmasının ilk aşaması, kalitenin bir ihtiyaç olarak hissedilmesidir. Bu ihtiyaçla birlikte eğitim araçlarında kalitenin artırılması eğitimde kaliteyi sağlar. Bunlar genel olarak; öğretmen, öğrenci, bilgi kaynakları, araç gereçler, tesis, veli ve yönetim olarak alınabilir.

1739 sayılı Milli Eğitim Temel Kanununun 43. Maddesinde; “Öğretmenlik mesleği, devletin eğitim, öğretim ve bununla ilgili yönetim görevlerini üzerine alan özel bir ihtisas mesleği" olarak tanımlanmaktadır. Bu meslek grubunun niteliği ve yeterliliği eğitim öğretim faaliyetinin başarıya ulaşmasında en önemli faktördür (Büyükkaragöz,1998).

Sistemin öngörüldüğü gibi çalışması için öğretmenin belirli özelliklere sahip olması gerekmektedir. Bu özellikler eğitim fakültelerine öğrenci seçerken ve seçilen öğrencileri yetiştirirken dikkate alınmak zorundadır. ABD Finlandiya gibi ekonomik güce sahip birçok ülke öğretmenlik mesleğini seçme aşamasında öğrencilerden sahip oldukları tutum, kişilik özellikleri ve iletişim becerileri hakkında referans mektupları istemektedirler(Atanur-Başkan, Aydın, vd.,2006 ; Ekinci ve Öter, 2010).

Ekinci ve Öter (2010)'in Finlandiya'da eğitim ve öğretmen yetiştirme sistemini inceledikleri çalışmalarında öğretmenin genel yeterlik alanları şöyle belirlenmiştir:

- Öğrencilerin bireysel farklılıklarının farkında olma ve saygı duymak,

- Diğer öğretmenlerle işbirliği ve iletişim halinde olmak,

- Aileler ve toplumun çeşitli kollarıyla ortak çalışmalar yapmak,

- Etkili ve uygun öğrenme ortamları ve materyalleri hazırlamak ve geliştirmek,

- Mesleki gelişimini devam ettirmek

Ülkemizde de Avrupa Birliği Komisyonu 8 Şubat 2000 tarihinde imzalanan Finansman Anlaşmasıyla yürürlüğe giren temel eğitime destek projesi kapsamında öğretmen nitelikleri belirlenmiştir. Projenin genel amacını; "Yoksulluğu azaltma perspektifinde, eğitim seviyesini artırarak, eğitim kalitesini ve eğitime erişimi iyileştirmek, en dezavantajlı kırsal, şehirsel bölgeler ve gecekondularda nüfusun hayat şartlarını geliştirmek, eğitim dışında kalan çocukların, gençlerin ve yetişkinlerin temel eğitim kapsamına alınması ve öğretmen arzının iyileştirilmesini desteklemek" oluşturmaktadır. 2002 yılında faaliyete geçen projenin sonucunda 2004 yılında yapılan bu çalıştaylar sonucunda öğretmenlik mesleği genel yeterlikleri;

A. Kişisel ve Meslekî Değerler - Meslekî Gelişim,

B. Öğrenciyi Tanıma,

C. Öğrenme ve Öğretme Süreci,

D. Öğrenmeyi, Gelişimi İzleme ve Değerlendirme,

E. Okul-Aile ve Toplum ílişkileri,

F. Program ve Iç̧erik Bilgisi,

olmak üzere 6 ana yeterlik alanı, bu yeterliklere ilişkin 31 alt yeterlik ve 233 performans göstergesi şeklinde belirlenmiştir ( MEB, 2008).

Bu yeterlik alanları incelendiğinde öğretmenin sahip olması gereken özellikler görülebilmektedir. Bir öğretmen iyi bir model olabilmek için kazandırması gereken özellikleri kendisi de taşımalıdır. 
Şen ve Erişen (2002)'ye göre etkili öğretmenler girişken, dostça davranan, sabırlı, hassas, iyi huylu, neşeli ve öğrencilerine arkadaşça davranan öğretmenlerdir. Aynı zamanda bu özellikler kalite eğitiminde görev alan öğretmenlerin sahip olması gereken özellikler olarak nitelendirilebilir.

Kaliteli eğitim; sürece öğrencinin dâhil edildiği bütünleşik bir sistemdir. Okullarda kalite uygulamaları ve bunu kabullenmiş öğrencilerin olması öğretmenin profesyonelleşmesine olanak sağlar. Özgürce fikir üreten öğretmen uzmanlaşır ve iş doyumu yaşar. Kalite uygulamalarının olduğu okullar toplum tarafından akademik alanlardan yoksun okullar olarak görülebilmektedir. Aslında akademik başarı eğitimin sıradan disipliner ve otoriter yönetimiyle gelmez. Başarı için;

- Düşünmenin önemini algılamak gerekmektedir.

- Heterojen sınıflar oluşturulmalıdır.

- Sıralama yapan A-B-C-D gibi notların kaldırılması gerekmektedir.

- Değerlendirme alanı olarak akademik ve sosyal gelişim öğretmence izlenmeli ve raporlaştırılmalıdır (Glasser, 1999).

Eğitimde kalitenin sağlanması öğretmende kalitenin sağlanması ve eğitim sürecinin kaliteli planlanması ile mümkün değildir. Kaliteden bahsedebilmek için tüm paydaşların sürece dahil olası gerekmektedir. En önemli paydaşlar biri de okul çevresidir. Okulu yaşayan bir çevre olarak görüp kaliteli okul oluşturmak gerekmektedir. Ve bu süreçte Glasser (2000) şu hususlardan bahsetmektedir.

i. İçten ve destekleyici bir sınıf ortamı olmalıdır.

ii. Öğrenciden yalnızca yararlı çalışma yapmaları istenmelidir.

iii. Öğrenciden her zaman ellerinden gelenin en iyisini yapmaları istenir.

iv. Öğrenciden kendi çalışmalarını değerlendirmeleri ve geliştirmeleri istenir.

v. Kaliteli çalışma her zaman iyi hissettirir.

vi. Kaliteli çalışma asla yıkıcı değildir.

Kaliteli okul yönetimi ile birlikte bir bütündür. Ve yönetimin Glasser'e göre (1999) patronca değil liderce yapılması gerekmektedir. "Başarısızlığın olmadığı okul" eseri ile yönetim durumunu işçi patron ilişkisiyle açıklayan Glasser (1999) şunlara dikkat çekmiştir:

Patronca yönetim unsurları:

i. Tüm standartları belirleyen patrondur. İş̧iler bunlara uymak zorundadırlar.

ii. Verilen iş gösterimi yapılmaksızın beklenir.

iii. Patron ya da görevli kişi işi denetler.

iv. İşçiler direnirse patron ceza uygular.

Patronca yönetimin aksine liderce yönetimde tüm enerji çalışanların kaliteli iş çıkarmaya harcanır. Bu yönetimin ana unsurları şöyledir:

i. İş̧iler yapılacak işin kalitesine onu yapmak için gereken zamana yönelik tartışırlar böylelikle işçiler işe katkı yapma fırsatına sahip olurlar.

ii. İş̧ilere işi nasıl yapacağı gösterilir

iii. Her işçi kendi çalışmasını denetler

iv. İş için en iyi araçlar işçiye sunulur ve huzurlu bir ortamda çalışmaları sağlanır.

Sürecin tüm paydaşlarında kalitenin sağlanması doğal olarak nitelikli çıktıları oluşturacaktır. Farklı ülkelerinin eğitim düzeyi için öğretmen yeterlilikleri incelenmiş ve genellikle aynı kanıya varılmıştır (Akyüz,2003; Seferoğlu, 2004). Öğretmen niteliğindeki artış öğrenci başarısını ve eğitim niteliğindeki artışı beraberinde getirmektedir (UNESCO,2001; Akyüz,2003). Ekonomik Kalkınma ve İşbirliği Örgütü (OECD) tarafından 2012 yapılan Uluslararası Öğrenci Performansı 
Değerlendirme Programı (PISA/Programme for International Student Assessment) araştırmasında öğretmenlerin niteliklerinin ve sayısının yetersiz olması, öğrenci performans düşüklüğünün nedeni olarak gösterilmektedir (OECD, 2012). Bu durum eğitimde kaliteyi artıracağından çalışmada kaliteli okul kavramının yanında eğitimde kalite için öğretmen seçme ve yetiştirmede kalite ve nitelikli öğretmen özellikleri de araştırılmıştır. Öğretmenlerin görüşleri ile alanyazında bu hususta yapılan diğer araştırmalar karşılaştırılmış öğretmen yetiştiren kurumlara, ilgili bakanlıklara önerilerde bulunulmuştur.

\section{AMAÇ}

Bu çalışma öğretmenlerin eğitimde kalite konusunda görüşlerini belirlemek amacıyla yürütülmüştür. Kalitenin artırılması için çalışması gereken iç paydaşların başında gelen öğretmenlerin çözüm önerileri ile eksikliği duyulan alanlara ışık tutmak hedeflenmektedir. Çalışma amacına yönelik olarak araştırmada şu soruların yanıtlanmasına çalışılıışır:

i. Öğretmenlerin öğretmen seçme ve yetiştirmede kalite hakkındaki görüşleri nelerdir?

ii. Öğretmenlerin kaliteli öğretmen hakkındaki görüşleri nelerdir?

iii. Öğretmenlerin kaliteli okul hakkındaki görüşleri nelerdir?

\section{YÖNTEM}

Çalışmada hedeflenen noktalara ulaşmak için derinlemesine araştırma yapmaya olanak sağlayan nitel araştırma türlerinden durum çalışması kullanılmıştır. Sınırlandırılmış bir zaman dilimi içerisinde bir durumun derinlemesine incelendiği durum çalışması ile temalar tanımlanmaya çalışılmıştır (Creswell, 2007).

\section{1. Çalışma Grubu}

2015-2016 Eğitim Öğretim yılının ilk döneminde kartopu örnekleme yöntemiyle tespit edilmiş 14 öğretmen bu araştırmanın çalışma grubunu oluşturmaktadır. Kartopu örnekleme yönteminde süreç konuyla ilgili veri toplanabileceği düşünülen bireylere ulaşıp o kişilerin tavsiye ettiği veri kaynaklarına ulaşma ile devam etmektedir. Bu şekilde birikerek ilerleyen veri kartopunu anımsatmaktadır. Araştırmacı süreci yeterli veriye ulaştığında ya da önerilen isimler aynılaşmaya başladığında sonlandırabilir (Yıldırım\&Şimşek, 2016). Örnekleme yöntemi dolayısıyla araştırmacı tarafından amaçlı olarak okulunda Toplam Kalite Yönetimi çalışmaları sürdüren bir öğretmen seçilmiştir. Seçilen kişi ve onları seçtiklerinin tercihleri ile veriler aynı isimlere dönene kadar devam edilmiştir. Öğretmenlerin tamamı İç Anadolu bölgesinin doğusunda yer alan bir ilde görev yapmaktadır. il sosyo-ekonomik düzey olarak orta seviyelerdedir. Katılımcı öğretmenlerin demografik özellikleri aşağıdaki tabloda belirtilmiştir. 
Tablo 1 Çalışma Grubunun Demografik Özellikleri

\begin{tabular}{|c|c|c|c|c|}
\hline \multirow{3}{*}{$\begin{array}{l}\text { MESLEKI } \\
\text { TECRÜBE }\end{array}$} & \multicolumn{4}{|c|}{ CINSIYET } \\
\hline & ERKEK & & KADIN & \\
\hline & $\mathbf{N}$ & $f$ & $\mathbf{N}$ & $f$ \\
\hline 1-5 YIL & - & - & 3 & $\% 21$ \\
\hline 6-10 YIL & 1 & $\% 7$ & 6 & $\% 42$ \\
\hline 11-15 YIL & 1 & $\% 7$ & 1 & $\% 7$ \\
\hline 16-20 YIL & - & - & 1 & $\% 7$ \\
\hline $20-25$ YIL & 1 & $\% 7$ & - & - \\
\hline TOPLAM & 3 & $\% 21$ & 11 & $\% 79$ \\
\hline
\end{tabular}

Çalışmanın sınırlılığı olan cinsiyet dağılımındaki eşitsizlik tabloda görülmektedir. Katılımcıların $\% 21^{\prime} i$ erkek öğretmenlerden \% 79'u kadın öğretmenlerden oluşmaktadır. Katılımcı öğretmenlerin mesleki tecrübeleri \%64 ile 6 ila 15 yıl arasında çoğunluk oluşturmaktadır.

Tablo 2 Çalışma Grubu Öğretmenleri Branş Dağılımları

BRANŞLAR N f

Sosyal bilgiler öğretmeni $\quad 3 \quad \% 21$

Sınıf öğretmeni $\quad 3 \quad \% 21$

Ingilizce öğretmeni $\quad 2 \quad \% 14$

Okul öncesi öğretmeni $\quad 1 \quad \% 7$

Özel eğitim öğretmeni $\quad 1 \quad \% 7$

Din kültürü ve ahlak bilgisi $\quad 1 \quad \% 7$

öğretmeni

Türkçe öğretmeni $\quad 1 \quad \% 7$

Matematik öğretmeni $\quad 1 \quad \% 7$

Metal işleri öğretmeni $\quad 1 \quad \% 7$

Çalışma grubunu oluşturan öğretmenlerin \% 21 Sosyal bilgiler öğretmeni; \% 21 Sınıf öğretmeni; \%14 İngilizce öğretmeni; \% 7 Okul öncesi öğretmeni; \%7 Özel eğitim öğretmeni; \% 7 Din kültürü ve ahlak bilgisi öğretmeni; \%7 Türkçe öğretmeni; \% 7 Matematik öğretmeni; \%7 Metal işleri öğretmenidir.

Öğretmenlerin okullarda Toplam Kalite Yönetimi çalışmalarında bulunan kişiler olması ve her okuldan bir kişi ile görüşülmüş olması branş dağılımlarını farklılaştırmıştır. Okulların \% 7'si Endüstri meslek lisesi, \% 7 'si Anadolu lisesi, \% 7'si İmam Hatip Okulu, \% 7'si Anaokulu, \% 35'i Ortaokul, \% 35'i ilkokuldur.

\subsection{Verilerin Toplanması ve Analizi}

Veri toplama aracı olarak kullanılan yarı yapılandırılmış görüşme formu araştırmacılar tarafından alt problemlere yönelik sorularla hazırlanmıştır. Pilot uygulama yapılarak alternatif soru kullanımları belirlenmiştir. Görüşmeler öncesi yarı yapılandırılmış görüşme formunun iki uzman görüşü alınarak kapsam geçerliği sağlanmıştır ve son hali verilmiştir. Yarı yapılandırılmış görüşme formu 14 açık uçlu sorudan oluşmaktadır. Araştırmada güvenilir veriler elde etmek için katılımcıların güvenini sağlamaya titizlik gösterilmiştir. Derinlemesine veri toplayabilme amacı ile araştırmaya katılacak olan kişilere çalışma hakkında ayrıntılı bilgi verilmiştir. Bu yolla gönüllü katılımcı aranan çalışmada ilk olarak gönüllü olan kişinin farklı bir ilden oluşu örneklem sebebiyle tüm grubun araştırmacıya uzak bölgeden olmasına neden olmuştur. Bu sebeple araştırmacı ekonomiklik ilkesine uymak için görüşmeleri internet ortamında canlı görüşme yapabilmeyi 
sağlayan Skype programıyla sürdürmeyi tercih etmiştir. Kişilerle rahat konuşabilecekleri ortamlar hazırlayabilme konusunda ön görüşmeler yapılmış randevular alınmıştır. Bu programın veri toplamada kullanılmış olması kişilerin randevu saatlerine uymada araştırmacıya kolaylıklar sağlamıştır. Görüşmeler sırasında araştırmacı tarafından gözlemlendiği kadarıyla öğretmenler kendi ortamlarında bulunmanın rahatlığını konuşmalarındaki içtenlikle hissettirmişlerdir. Görüşmeler kişilerin de onayı alınarak ses kayıt cihazı ile kaydedilmiştir. Kayıtlar yazıya dökülmüş ve her kişinin yanıtlar formu kendisine kontrol ettirilmiştir. Böylece yanlış anlaşılmaların önüne geçilmeye çalışımıştır.

Verilerin analizinde içerik analizi yönteminden faydalanılmıştır. İçerik analizinde temel amaç, toplanan verileri açıklayabilecek kavramlara ve ilişkilere ulaşmaktır. Bu amaçla toplanan verilerin önce kavramsallaştırılması, daha sonra da ortaya çıkan kavramlara göre mantıklı bir biçimde düzenlenmesi ve buna göre veriyi açıklayan temaların saptanması gerekmektedir (Yıldırım ve Şimşek, 2016). Her bir kod için toplam katılımcı sayısı üzerinden yüzdelik hesabı yapılarak tablolaştırılmaya gidilmiştir.

Görüşmelerden elde edilen verilerin kodlanması sırasında alanında uzman bir dış denetçiden yardım alınmıştır. Dış denetçi ile karşılıklı görüş alış verişinde bulunarak elde edilen sonuçlar aşamalı olarak birlikte değerlendirilmiştir. Yapılan kodlama dışında ikinci bir kodlama yapılmış ve kodlayıcılar arasındaki uyum için Miles ve Hubberman'ın (1994) formülü kullanılmıştır. Yüzde uyumu $\% 81$ olarak bulunmuştur. Uyumun $\% 70$ 'in üzerinde olması kodlayıcılar arasında uyum olduğunu göstermektedir ( Miles ve Hubberman, 1994).

\section{BULGULAR}

Bu bölümde öğretmenlerin görüşlerinin analizinden elde edilen bulgulara yer verilmektedir.

\subsection{Probleme yönelik bulgu ve sonuçlar: Öğretmen seçme ve yetiştirmede kalite.}

Öğretmen seçme ve yetiştirmede kalitenin yordanması için öğretmenlerin mesleklerinde kendilerini sorumlu tuttukları alanlar belirlenmeye çalışılmışır. Ortaya çıkan sorumlulukların eğitim fakültelerinde ne derece geliştirildiğini düşündükleri araştırımıştır. Birbirini açıklayan böyle nedenler dolayısıyla çalışmada problemler alt başlıklarla yorumlanmaya çalışılmıştır.

\subsection{1. Öğretmenlerin mesleğe dair görev tanımları}

Öğretmenlere ilk olarak mesleğe dair görev tanımlarını belirlemek amacıyla sorular yöneltilmiştir. Elde edilen görüşler analiz edildiğinde ortaya çıkan sonuçlar tablo 3 de yer almıştır.

Tablo 3 Öğretmenlerin Mesleğe Dair Görev Tanımları

\begin{tabular}{lll}
\hline & $\boldsymbol{N}$ & $\boldsymbol{f}$ \\
\hline Ĕ̆itim öğretim sürecini yürütür & 7 & $\% 50$ \\
Öğrenciyi hayata hazırlar & 5 & $\% 35$ \\
Kutsal-onurlu meslek & 4 & $\% 28$ \\
Anne- babalık gibidir & 2 & $\% 14$ \\
Topluma rehberlik eder & 2 & $\% 14$ \\
Vatana millete hayırlı vatandaş & 2 & $\% 14$ \\
yetiştirir & &
\end{tabular}

Katılımcı öğretmenler meslek tanımlarını yaparken \%50 oranıyla eğitim öğretim işlerini yürütmekten söz etmişlerdir. Bunun yanı sıra katılımcıların $\% 28$ 'i mesleğin kutsal-onurlu olduğunu; \%35 öğrenciyi hayata hazırladığını; \%14anne babalık gibi olduğunu; \% 14Topluma rehberlik eden bir meslek olduğunu; \%14 vatana millete hayırlı vatandaşlar yetiştirdiklerini dile 
getirmişlerdir. Katılımcılardan "Vatana millete hayırlı vatandaş yetiştirir" kategorisinde değerlendirilenK2 bu konuda fikrini şöyle belirtmektedir:

".....Öncelikle insan olmak, insani değerlere önem vermek gereklidir. Bunun yansıra milli, manevi ve vicdani değerler de tam olarak bütünleşmeli. idealist ve vizyonlu bir insan olmak da şart biz eğitimci olarak her konuda çocuklarımıza modeliz, hanım öğretmenler olarak kızlarımıza, erkek öğretmen olarak oğullarımıza..."

"Öğrenciyi hayata hazırlar ve eğitim öğretim sürecini yürütür" kategorilerinde değerlendirilen K7 bu konuda fikrini şöyle ifade etmektedir.

“...Kişilerin yeteneklerinin keşfedilip geliştirildiği, hayata dair bilgilerin aktarıldığı bir meslek dalı diyebiliriz. Kişiyi hayata bağlamalı, Hayata pozitif bakış açısı kazandırmalı, Belirlenen plan doğrultusunda öğrenciye gerekli bilgi, beceriyi sabır, hoşgörü ve istekle kazandırabilme, Öğrenciyi keşfedip geliştirebilme, Eğitim öğretim sürecinde öğrenci vb. nedenlerle oluşan sorunları fark edip çözüm bulabilme, Öğrencilerin başarılı olmalarına yardımcı olmak ve başarılarını değerlendirmek...."

Genel olarak değerlendirildiğinde öğretmenler mesleği eğitim öğretim sürecini yürüten kişi olmanın yanı sıra öğrenciyi hayata hazırlayan kutsal bir meslek olarak da tanımlamaktadırlar.

\subsubsection{Eğitim Fakültelerine Öğrenci Seçimi}

Meslek tanımlamalarından sonra öğretmenlere kendilerinin belirlediği sorumlulukları yerine getirecek olan kişilerin eğitim fakültelerine seçimi konusunda düşünceleri sorulmuştur. Yanıtlar Tablo 4 te kategorileştirilmiştir.

Tablo 4 Öğretmenlerin Eğitim Fakültelerine Öğrenci Seçimi Konusunda Düşünceleri

\begin{tabular}{lcc}
\hline & $\boldsymbol{N}$ & $\boldsymbol{f}$ \\
\hline Yeterli değil & 10 & $\% 71$ \\
$\begin{array}{l}\text { Kişilik } \\
\text { incelenmesi }\end{array}$ & 7 & $\% 50$ \\
$\begin{array}{l}\text { Psikolojik durum araştırması } \\
\text { Yeterli }\end{array}$ & 3 & $\% 21$ \\
Illgi ve sevgi tespiti & 3 & $\% 21$ \\
Herhangi bir fikrim yok & 2 & $\% 14$ \\
\hline
\end{tabular}

Katılımcı öğretmenlerin tamamı sonradan gelişmesi zor olduğunu düşündükleri özelliklerin öğrenci seçimi politikasında dikkate alınması gerektiği hususunda hemfikir değildirler. Çalışma gurubuna dâhil olan öğretmenlerin \%71'ibu tarz sınavların yeterli olmadığını belirtirken; kişilik özelliklerinin, psikolojik durumlarının, ilgi ve sevgilerinin tespitinin gerekliliğinden söz etmişlerdir. Bu seçimlerin de adaletli olmasına değinen K3 bu konuda şöyle düşünmektedir:

"Bence eğitim fakültelerine yerleştirilebilmek için kişinin kişisel özelliklerine de bakılmalı ve öğretmenlik vasıflarını taşıyıp taşımadığı ölçülmeli. Tabi ki bu objektif olmalı."

Fikri "yeterli" kategorisinde değerlendirilen $\mathrm{K} 8$ bu konuda fikrini şöyle belirtmiştir.

"...ösym öğrenciyi seçmek için bence gayet iyi çalışıyor. Çocuğun aldığı puan seviyesini iyi belirliyor yani. Bu sebeple bence iyi bir değerlendirme yapılıyor...."

Öğretmenlerin çoğunluğu eğitim fakültelerine öğrenci alınırken merkezi sınavların yapmış olduğu değerlendirmeyi yeterli bulmadıklarını belirtmişlerdir. Özellikle kişilik testlerine tabi tutulmaları gerektikleri katıımcı öğretmenlerin yarısı tarafından vurgulanmıştır. 


\subsubsection{Eğitim fakültesinden hatırlananlar}

Öğretmende kalitenin seçimle başlayacağını vurgulayan katılımcılarımıza, kalitenin devamı için eğitim fakültelerinin rolü sorulmak istenmiştir. Bu sebeple önce kendilerinin eğitim fakültesinde geçirdiği yıllar hatırlatılarak onlarda bıraktığı izler tespit edilmeye çalışılmıştır.

Tablo 5 Öğretmenlik Eğitimi Sürecinden Hatırladıkları Dersler

\begin{tabular}{lll}
\hline & N & $\boldsymbol{f}$ \\
\hline Uygulama dersleri & 9 & $\% 64$ \\
Branş dersleri & 5 & $\% 35$ \\
Olumsuzluklar & 4 & $\% 28$ \\
Pedagojik dersler & 2 & $\% 14$ \\
\hline
\end{tabular}

Öğretmenlere eğitim fakültelerinin verdiği eğitim kalitesini sorgulatmak için kendilerine aldıkları derslerden hangilerini ne şekilde hatırladıkları sorusu yöneltilmiştir. Katılımcılar çoğunlukla (\%64) uygulama derslerini öncelikli olarak hatırladıklarını vurgulamışlardır. Fakat uygulama yaptıkları dersler arasında toplamda 15 ders ismi sıralanmıştır. Farklı branşlardan olan örneklem grubunun eğitim fakültelerinde aldıkları ders sayısı ortalama 60-70 arasında değişmektedir. Bu grubun toplamda aldıkları ders sayısı, ortak dersler hesaba katılarak hesaplandığında yaklaşık 420 farklı ders tespit edilebilir. Yaklaşık 420 dersten sadece 15 inin isminin sayılabiliyor olması derslerin yapılandırıcı yaklaşımdan uzak olarak işlendiğini gösteriyor olabilir.

Öğretmen adaylarına eğitim fakültelerinde aldıkları eğitimi genel olarak değerlendirmeleri için meslek hayatında etkili olarak kullandıkları bilgilerin kaynağı kendilerine sorulduğunda öğretmenlerin tamamı mesleğin aslında süreçte öğrenildiğini eğitim fakültesinde alınan teorik bilgileri uygulamaya geçirirken zorlandıklarını dile getirmişlerdir. Bu durumun yanı sıra Katılımcı grubundan K7 aldığı ilk okuma ve yazma dersinin içerik olarak uygulama oluşu dolayısıyla 1. Sınıf öğrencilerine okuma yazma öğretiminde hiç zorlanmadığını dile getirmiştir.

Olumsuzluklar kategorisinde değerlendirilen K11 ise şu sözlerle kendini ifade etmiştir:

“.... daha çok şey var aslında anlatacak. Ben isim vermeden konuşayım. Bunların hepsi hoca diye dolaşıyor ortalıkta. Ne ders gördük ne başka bir şey. 4 yıl geçti gitti adamların laklaklarıyla...."

Öğretmenlerin genel olarak uygulama derslerini ve pedagojik dersleri hatırladıkları söylenebilir.

\subsection{4. Öğretmen yetiştirmede kaliteyi artırmak için yapılması önerilenler}

Kendilerinden yola çıkarak eğitim süreçlerini sorgulayan öğretmenlerimizden kalite için yapılması gerekenler sorulmuştur. Verdikleri yanıtlar tablo 6 da sunulmuştur.

Tablo 6 Katılımcıların Öğretmen Yetiştirme Sürecinde Eğitim Kalitesini Artırma Yollarına Dair Görüşleri

\begin{tabular}{lcc}
\hline & $\boldsymbol{N}$ & $\boldsymbol{f}$ \\
\hline Uygulama derslerinin artırılması & 8 & $\% 57$ \\
Ders içeriklerinin düzenlenmesi & 4 & $\% 28$ \\
Yurt dışı eğitim zorunluluğu getirilmeli & 2 & $\% 14$ \\
Değer eğitimine önem verilmeli & 1 & $\% 7$ \\
Yüksek seviye öğrenci alımı sağlanmalı & 1 & $\% 7$ \\
Anadolu öğretmen liselerine geri dönülmeli & 1 & $\% 7$ \\
Kültürel yapının tanıtımı & 1 & $\% 7$ \\
\hline
\end{tabular}


Eğitim sürecini tamamlamış olan katılımcılara öğretmen yetiştirmede neler yapılması daha kaliteli öğretmen olmanızı sağlardı diye sorulduğunda, katılımcıların \% 57'si uygulama derslerinin daha fazla olması gerektiğinden bahsetmişlerdir. Bu uygulama derslerinin öğretmenlik uygulamaları olduğunu ve bu dersin sürecin başından sonuna her yıl verilmesi gerektiğini vurgulamışlardır. Katılımcıların \%28'i fakültede okutulan ders içeriklerinin eğitim programlarında öngörülen yapılandırıcı yaklaşımla tekrar düzenlenmesi gerektiğini belirtmişlerdir.\%14 oranında yurt dışı eğitim zorunluluğu;\%7 değer eğitimine verilen önemin artırılması gerekliliği, \%7alınan öğrencilerin daha yüksek seviye olması gerekliliği,\%7 Anadolu öğretmen liseleriyle temelden yetiştirme programının tekrar getirilmesinin gerekliliği, \%7 kültürel yapının tanıtımının gerekliliği vurgulanmıştır.

Fakülteye seçilen öğrenci seviyesinin öğretmen yetiştirmede kaliteyi artıracağını düşünen K11 fikrini şöyle belirtmiştir: "Bence öncelikle öğretmen olabilecek kişiler bu mesleği yapmalı. Ayrıca ülkemizde bir meslek grubu ne kadar çok saygı görüyorsa ve para kazanıyorsa bu meslek o kadar değeli hale geliyor. Yani öğretmene verilen değer maddi ve manevi olarak geliştirilebilirse o zaman öğretmenlik eğitimini seçecek olan gençler işlerini daha çok sahip çıkacaklar ve daha çok emek harcayacaklardır. Böylece eğitim fakültelerine gelen öğrencilerin seviyesi artacak. Akademisyenlerin elinde şekillenecek olan hamur kaliteli olacak. Sonuç olarak kaliteli öğretmen ortaya çıkacak."

Kültürel yapının mesleğe başlamadan tanıtımının önemli olduğunu K3 şöyle vurgulamıştır.

"Mesleki bilgi ve beceriler öğretmenlere aktarılmalı, ama asıl önemli olan Türkiye'nin fiziki şartları doğrultusunda okulların olanakları, her yörenin kültürel özellikleri anlatılmalı. Bizler mesleğimizin asıl yüzünü mesleğe başlayınca fark ettik. Fikrimce öğretmen yetiştirirken mesleğin tüm gerçek yüzünü yani ülkemizin her bölgesine ait haklın kültürel yapısı ve okul eğitim olanaklarını anlatabilen dersler üniversitede olmalı."

Uygulama derslerinin artırılması ve ders içeriklerinin yeniden düzenlenmesi kategorisinde değerlendirilen $\mathrm{K} 5$ fikrini şöyle dile getirmiştir.

"...yani bence böyle. Hiç yapılmadı bizim zamanımızda. Derslerin çoğu saçma sapan geçti gitti. Bir kere o verilen derslerde anlatılan hiçbir şey yok bugün müfredatta. Bu sebeple o dersler bir yeniden düzenlenmeli. Ayrıca uygulama dersleri çok fazla olmalı..."

Yurt dışı eğitim zorunluluğundan ve değer eğitimine önem verilmesinden bahseden öğretmen K12 düşüncelerini şöyle dile getirmiştir.

" Bence biraz da örnek almalıyız artık. Avrupa da insanlar öncelikli olarak değer eğitimine önem veriyorlar. Dersler hep ikinci planda kalıyor. Bence dünyanın sorunu da bu. Önce insan yetiştirmeliyiz. Eğitim fakültesini bitiren her genci göndersinler iki aylığına yurt dışına bir kuruma....."

Öğretmenlik mesleğinde kalitenin öğretmen yetiştirme sürecine erken başlamakla olduğunu vurgulayan $\mathrm{K} 2$;

" önceden daha iyiydi sanki. Öğretmenler liselerden yetişirdi. Nasıl demiş atalarımız... Ağaç yaşken eğilir. Yani siz bir kimseyi öğretmen yapmak istiyorsanız, daha doğrusu kaliteli bir öğretmen olarak yetiştirmek istiyorsanız onu erken yaşlarda eğitmelisiniz..." sözleriyle fikrini açıklamıştır.

Verilen yanıtlar genel olarak değerlendirildiğinde öğretmen yetiştirmede kalitenin nasıl artırılacağı konusunda fikirlerin uygulamaya dönük derslerin çoğalması, eğitim fakültelerinde okutulan derslerin içeriklerinde düzenlemeye gidilmesi üzerinde yoğunlaştığı görülmektedir. 


\subsection{Probleme yönelik bulgu ve sonuçlar: Kaliteli öğretmen}

Katılımcı grubuna eğitimde kaliteyi artırmak için var olması gereken öğretmenin özelliklerini irdeleyen sorular yöneltilmiştir. Ve bulgular başlık altında yorumlanmıştır.

Tablo 7 Öğretmenlerin "Bir Öğretmenin Sahip Olması Gereken Özellikler" Konusunda Düşünceleri

\begin{tabular}{lcc}
\hline & $\boldsymbol{N}$ & $\boldsymbol{f}$ \\
\hline Sabırlı & 10 & $\% 71$ \\
Sosyal & 8 & $\% 57$ \\
Sevgi dolu & 6 & $\% 42$ \\
Model & 6 & $\% 42$ \\
Hoşgörü sahibi & 5 & $\% 35$ \\
Meraklı & 5 & $\% 35$ \\
Yenilikçi & 3 & $\% 21$ \\
İyi niyetli & 3 & $\% 21$ \\
Planlı & 3 & $\% 21$ \\
Azimli & 3 & $\% 21$ \\
Ön yargısız & 3 & $\% 21$ \\
İealist & 2 & $\% 14$ \\
Güvenilir & 1 & $\% 7$ \\
Özgüveni yüksek & 1 & $\% 7$ \\
Disiplinli & 1 & $\% 7$ \\
Otoriter & 1 & $\% 7$ \\
Dürüst & 1 & $\% 7$ \\
Fedakâr & 1 & $\% 7$ \\
Teknoloji odaklı & 1 & $\% 7$ \\
\hline
\end{tabular}

Katılımcı öğretmenler bir öğretmenin sahip olması gereken özellikler arasında çoğunlukla sabırlı, sosyal, sevgi dolu, hoşgörülü, model, meraklı olmaktan söz etmişlerdir. Bu özelliklerin kişinin öğretmen yetiştirme sürecinde aldığı eğitimle geliştirilip geliştirilemeyeceği konusunda fikirleri sorulduğunda ise katılımcı öğretmenlerimizin tamamı bu özelliklerin karakteristik olduğunu, doğru eğitimlerle az da olsa geliştirilebileceğini belirtmişlerdir. Kendilerinden örnekler sorulduğunda ise; kendi eğitim süreçlerinde bu özellikleri geliştirmeye yönelik hiçbir ders içeriğine rastlamadıklarını belirtmişlerdir. Katılımcılardan ikisi (K4 ve K7) bu özelliklerin meslek icrasında gelişebileceğinden söz etmiştir. Bu nedenle bu iki katılımcı öğretmen yetiştirme sürecinde öğretmenlik uygulamaları ders süresinin daha uzun tutulması gerektiğini savunmuşlardır. Katılımcı öğretmenlerden biri (K1) ise öğretmenlikte kariyer yükseltmeye destek verilmesi gerektiğini şu sözleriyle dile getirmiştir;

K1: "Eskiler hep derler ya, insanın içinde olmalı şeklinde gerçekten de öğrenme ve öğretme isteği insanın içinde olmalı... Kendini geliştiren öğretmenin de daha da geliştirebilmesi için olanaklar sağlanmalı her konuda teşvik edilmeli. Bunlar sözler değil somut adımlarla atılmalı. Örneğin Öğretmenlikte Kariyer Basamakları güzel bir uygulamaydı, daha da geliştirilmeli... Neticede insan psikolojisi bende aynı şeyi yapıyorum, o da farkımı ne sorusunu kişi kendine sorabilmeli, hakkaniyet ve adalet her kurumda olduğu gibi öğretmenlik mesleğinde de esas olmalı... Haksızlığa uğrayan birisi, adalet kavramını öğretebilir mi, ikinci olarak her türlü ideolojik ve kayırmacı politikadan uzaklaşılmalı çünkü kalıcı olan devlettir, bireydir. Günün şartlarına göre kararlar alınmamalı, yapılan her şey on yıl yirmi yıl sonrasına hitap ediyor, bu göz ardı edilmemeli."

Sayılan sıfatlar gözden geçirildiğinde birçoğunun ortak fikir ile dile getirildiği görülmektedir. Katılımcı öğretmenlerin pek çoğu mesleğin meşakkatli oluşundan bu nedenle bu 
işi yapacak kişilerin pek çok olumlu kişilik özelliğini bünyelerinde bulundurmaları gerektiğini vurgulamışlardır. Katılımcı öğretmenlerden K8 bu hususta fikrini şöyle dile getirmektedir;

"Öğretmenlik o kadar zor bir iş ki anlatamam. Sanırım beni ancak öğretmenler anlar. Ben öğrencimin ayakkabısını bağlamaktan tutun, sümüğünü silmeye kadar her türlü işi yaptım. Bu ne gerektirir? Tabiî ki sabır. Sonra fedakâr, sevgi dolu ve hoşgörülü olmalı öğretmen. Özellikle iyi de bir model olmalı..."

Aynı kategorilerde fikirleri değerlendirilen K3 ise şu sözlerle kendini ifade etmiştir;

"Allah aşkına şu dışarıdaki gürültüye bir bakın. Bunlar bir de lise öğrencisi. Biraz ağır olmalılar değil mi? Bunlara bir şeyler anlatmayı bırakın, aynı ortamda olmak için bile sabır taşı olmak gerek. Bir de zamane çocukları onların dilinden konuşmazsan seni topa tutarlar. Bileceksin onların neslini. Yenilikçi olacaksın. Bana ne ürünler sunuyorlar. Anlamasam beni hiç saymazlar."

Bulgular genel olarak değerlendirildiğinde öğretmenlerin meslek için sahip olunması gerekli en temel özellikler; sabırlı, sosyal, sevgi dolu, iyi bir model olmaktır.

\subsection{Probleme yönelik bulgu ve sonuçlar: Kaliteli okul}

Kaliteli bir okul ortamı için öğretmen ve öğrencilerin beklentileri farklılaşabilmektedir. Bu nedenle öğretmenlerin gözüyle, öğrencilerin okulu ne olarak gördükleri sorgulanmaya çalışılmıştır. Öğrenci istek ve ihtiyaçları doğrultusunda kaliteli okul için gerekli hususlar tespit edilmeye çalışımıştır. Yürürlükte olan Toplam Kalite Yönetimi uygulamalarının bahsedilen kalite odaklarına ne denli destek sağladığı araştırılmıştır. Tüm bu başlıkların değerlendirilmesi sonucunda öğretmenlerin eğitimde kalite için vurguladıkları hususlar yordanmaya çalışımıştır.

\subsection{1. Öğrencilerimizin gözünde "Okul”}

Okulun en önemli paydaşı olan öğrenci zamanının çoğunluğunu geçirdiği bu mekâna kendini ait hissetmelidir. Bu aidiyetin oluşmadığı durumlarda okullarda disiplin sıkıntıları doğmaktadır. Öğrencinin okuldaki yerini fark etme durumlarını incelemek için katılımcı öğretmenlerimize "Sizce öğrencileriniz okulu ne olarak görüyorlar?" sorusunu yöneltilmiş ve cevapları tablo 8 de sunulmuştur.

\section{Tablo 8 Öğrencilerin Okulu Ne Olarak Gördüklerine Dair Öğretmenlerin Düşünceleri}

\begin{tabular}{lcc}
\hline & $\boldsymbol{N}$ & $\boldsymbol{f}$ \\
\hline Oyun evi & 6 & $\% 42$ \\
Sosyalleşme alanı & 5 & $\% 35$ \\
Gereksiz bilgi yüklenen yer & 2 & $\% 14$ \\
Gitmek zorunda olduğu yer & 2 & $\% 14$ \\
\hline
\end{tabular}

Öğrencilerin kendilerini okulun bir parçası gibi hissedip hissetmediklerini tespit için öğretmenlere, öğrencilerin okulu nasıl bir yer olarak gördükleri sorulduğunda öğretmenlerimizin tamamı olumsuz sayılabilecek tanımlar yapmışlardır. Katılımcıların \%28'i bu olumsuz düşüncelerin öğrenci okula devam ettikçe arttığını lise döneminde isyan noktasına geldiğini belirtmişlerdir.

Okulu gitmek zorunda olunan yer olarak tanımlayan katılımcılar bunun sorumlusu olarak veliyi işaret etmektedirler. Velilerin çocuklarını okula gönderip rahat ettiklerini vurgulayan K3 bunu şu şekilde dile getirmiştir:

K3"Çoğu öğrenci için okul haftanın 5 günü sabah 8.30 dan akşam 16.30 a kadar zamanlarını geçirdikleri ve ailelerine yük olmadıkları duvarlarla çevrili mekandır."

Bu konuda K12 ise şu noktalara dikkat çekmiştir: 
"...biraz da kendimizi sorumlu tutmak gerek aslında. Topu çocuğa atmak kolay. Tamam çocuk istemiyor, sevmiyor ama bunun asıl nendi ne? Biz şimdiye kadar öğrenciye ne var ne yok öğretmeye çalıştık. Öğrendiği hiçbir şeyi hayatında görmedi bu çocuk. E tabi okula karşı fikri gereksiz bilgi doldurulan yer olacak."

K1: "...ben bir keresinde çocuğa madem öyle istemiyorsan gelme yavrum dedim. Çocuk bana ne dese beğenirsiniz. Ben mecbur olmasam hiç gelir miyim? Çocuk burayı mecbur olduğu yer olarak görüyor. Ne bir ihtiyaç var beyninde ne de istek..." sözleriyle bu hususta fikrini belirten katılımcı aynı zamanda "... Biz bazı projelerle çocuğu okula bağlamalıyız. Çocuk ait olma hissini tatmalı. Ancak o zaman bu iş olur." Diyerek yapılması gerekeni de açıklamıştır.

Bulgular genel olarak incelendiğinde öğretmenler öğrencilerin okula karşı olumsuz tutum besledikleri dikkat çekmektedir.

\subsubsection{Kaliteli okulun özellikleri}

Öğrencilerin gözünde okul simgesini olumsuz gördüklerini söyleyen öğretmenlerimize, bunun tersini yaratmak için okulun taşıması gereken özelliklerin neler olduğu sorulmuştur.

Tablo 9 Bir Okulun Kaliteli Olması İçin Gerekenler Konusunda Öğretmenlerin Görüşleri

\begin{tabular}{lcc}
\hline & $\boldsymbol{N}$ & $\boldsymbol{f}$ \\
\hline $\begin{array}{l}\text { Okulun mali durumunun iyi } \\
\text { olması }\end{array}$ & 4 & $\% 28$ \\
Velilerin eğitim seviyesi & 4 & $\% 28$ \\
Okulun fiziki şartları & 3 & $\% 21$ \\
$\quad$ Veli-öğretmen-öğrenci & 3 & $\% 21$ \\
ilişkisinin sağlamlığı & & \\
Öğrenci seçıminde kalite & 3 & $\% 21$ \\
Mezunların durumu & 2 & $\% 14$ \\
Çalışma ortamının kalitesi & 2 & $\% 14$ \\
Eğitim sisteminin kalitesi & 1 & $\% 7$ \\
Otorite & 1 & $\% 7$ \\
Sosyal- kültürel faaliyet & 1 & $\% 7$ \\
\hline
\end{tabular}

Katılımcı öğretmenlere bir okulun kaliteli olması için gerekenler sorulmuş ve alınan yanıtlar Tablo 9 da kategorileştirilmiştir. Öğretmenler kaliteli okul denildiğinde genellikle kaliteyi okulun fiziki ve mali durumuna, çevresel faktörlere bağlamaktadırlar. Böyle düşünen katılımcılardan K12 fikrini şöyle dile getirmektedir:

"Bir okulun kaliteli olması için öncelikle bakanlık-il-ilçe milli eğitimlerinin okulun fiziki şartlarını iyileştirmesi gerekir. Bunu yaparken de öğrenci, mahalle ve veli sosyo-ekonomik ayrım gözetmemesi gerekir."

Fiziki şartların iyiliğinden bahsederken bunu öğrencinin hayatı okulda görmesini sağlamak isteyen $\mathrm{K} 1$ ise şu sözlerle kaliteli okul yaklaşımını açıklamıştır:

"Elbette ki öğrencilerinin ve öğretmenlerinin yaşam kalitesine... Ama bunlardan maksat en pahalı, en lüks şeyler değil elbette. Imkanlar dahilinde her şeyi başkalarında bekleyerek değil, önemli olan az olandan güzel şeyler ortaya çıkarabilmek... idareci olduğum yıllarda okul tuvaletlerinde tuvalet fırçası bile yoktu öğrenci kırıyor diye koymuyorlardı, aynı şey çocuk gelişiminde de vardır vazo örneği çocuk vazoyla yaşamayı öğrenmelidir...500 kişilik okulda 50 kişi kırıyor diye biz 450 insanı cezalandıramayız... Babamın güzel bir sözü vardır; kızlarım her şeyi önce babalarının evinde görmeli ve ögrrenmeliler... Aynı şeyi okullarımıza uyarladım, uyarlamalıyız hep... Okulumuza çiçekler bile koymuştuk, eğitimde önemli olan sözle değil faaliyetle engelleri aşmak. Kütüphanesi, koridorlarında bile olmalı, temizlik hijyen, vitray, duvar 
boyaları, onları eğitim hayatının içinde bulundurmalıyız dışında değil... Ve herkesin illa ki tutulur bir yanı vardır oradan yakalamalıyız..."

Katılımcılardan yalnız biri K13 bunun öğrencinin aidiyet kazanmasıyla mümkün olabileceğini

"Yetiştirdiği bireylerin iş bulma düzeyine, mezun olan öğrencilerin kazandıkları üniversiteye, sosyal faaliyetlerin yeterince yapılmasına, kültürel faaliyetlerin yeterince yapılmasına ve sportif faaliyetlerin yapılmasına bağlıdır. Öğrencinin kendini okulun bir üyesi olarak görebilmesi önemlidir. Bunun yanı sıra insan ilişkilerinde iyi olan, sosyalleşebilen, toplum kurallarına uyan bireylerin yetişmesine bağlıdır." Diye açıklamıştır.

Bireyler bir şeyi ne kadar olumlu görürlerse görsünler çocukları üzerinden düşündüklerinde daha derinlemesine yanıtlar vermektedirler. Bundan faydalanarak öğretmen adaylarına çocukları varsa ya da ileride olursa onları ne tarz okullarda okutabilecekleri sorulmuştur. Öğretmenlerimizin tamamı hayatı birebir yaşayabileceği, sosyal kültürel faaliyetlerin öğrencinin ilgisince olduğu, çocuğun mutlu olabileceği, isteyerek gideceği, öğretmenin öğrenciye sevgi ile bağlandığı, idarecinin çözüm odaklı olduğu okulları tercih edeceklerini bildirmişlerdir. Bu hususların devlet ya da özel okullardan hangilerinde günümüzde daha sık bulunduğu sorulduğunda katılımcı öğretmenlerin 7'si (\%50) özel okullarda, 6'sı (\%42) devlet okullarında olduğunu belirtmişlerdir.

\subsubsection{Okullarda Toplam Kalite Yönetimi (TKY)}

Bakanlığımızın okullarda kaliteyi izledikleri kurullar olarak kurulan TKY 'nin işlevleri katılımcı öğretmenlerimize sorulmuş ve yanıtları Tablo 10 da sunulmuştur.

Tablo 10 Okullarda Toplam Kalite Yönetimi (TKY) Hakkında Öğretmenlerin Görüşleri

\begin{tabular}{lcc}
\hline & $\boldsymbol{N}$ & $\boldsymbol{f}$ \\
\hline Kâğıt üzerinde/ Formalite & 12 & $\% 86$ \\
Yetersiz uygulama & 12 & $\% 86$ \\
Hiç duymadım & 2 & $\% 14$ \\
\hline
\end{tabular}

Öğretmenlerimizin çoğu (\%86) okullarda uygulanan Toplam Kalite Yönetimi uygulamalarının formaliteden ibaret olduğunu belirtmişken 2'si (\%14) böyle bir uygulamanın varlığından haberdar değildir. Uygulamanın yeterli düzeyde olmadığını katılımcı öğretmenlerden K14 ve K10 sırasıyla şöyle dile getirmektedirler:

"Okullarda yürütülen toplam kalite uygulamaları yeterince kurumlar, öğretmenler ve diğer çalışanlar tarafından benimsenmedi. Resmiyette yapılıyor gibi gözükse de aslında uygulama mevzuatına uygun çalışmalar yapılmamaktadır. Yapılan çalışmalar da toplam kalite yönetimi çerçevesinde işlemlendirilememektedir."

"Genel anlamda bazı şeylerin kâğıt üzerinde kaldığını düşünüyorum, yapılan Çalıştaylar, toplantılar. Onlar okula gelinip öğrenci ve öğretmenle yapılmalı, eğitim bir yazboz tahtası değildir. Biz insanların geleceğini hazırlıyoruz, bir ülkenin kaderini... Masa başında kalmamalı her şey..." getirmişlerdir.

Hiç duymadım kategorisinde değerlendirilen öğretmenler fikirlerini şu şekilde dile K6:" ... öyle bir şeyler mı varmış hiç duymadım."

K9: "...duymadım, hatırlamıyorum"

Bu öğretmenlere okullarında kurulu olan komisyonda görevli oldukları hatırlatılmıştır. İmzalarını hatırlayan öğretmenler uygulamalar hakkında şöyle fikir beyan etmişlerdir. 
K6: "çok güldüm. Gerçekten zor hatırladım. Artık ne kadar faal çalıştığımızı siz anlayın."

K9: "...evet ya şimdi hatırladım. Tekaye deyip duruyoduk. Inan ne olduğuyla bile ilgilenmemişim. Işste uygulama süper."

Verilen yanıtlar incelendiğinde öğretmenlerin uygulamaların kağıt üzerinde oluşundan şikayetçi oldukları dikkat çekmektedir.

\subsubsection{Eğitimde Kaliteyi artırmanın yolları}

Bakanlığın kaliteyi artırmak için yönettiği uygulamalardan memnun olmadıklarını belirten öğretmenlerimizden problem için çözüm önerileri sunmaları istenmiştir. Görüşler tablo 11 de sunulmuştur.

\section{Tablo 11 Öğretmenlerin Eğitimde Kaliteyi Artırmanın Yolları Hakkındaki Görüşleri}

\begin{tabular}{lcc}
\hline & $\boldsymbol{N}$ & $\boldsymbol{f}$ \\
\hline $\begin{array}{l}\text { Nitelikli aile eğitimi } \\
\text { Veli-öğretmen-öğrenci ilişkisini }\end{array}$ & 7 & $\% 50$ \\
güçlendirme & 6 & $\% 42$ \\
Fiziki şartların iyileştirilmesi & 5 & $\% 35$ \\
$\quad$ Eğitim sisteminin yenilenmesi & 4 & $\% 28$ \\
$\quad$ Öğretmenlik mesleğine gerekli & 3 & $\% 21$ \\
maddi manevi önemi verme & & \\
Ilgiye- yeteneğe yönelme & 1 & $\% 7$ \\
Kaliteli öğretmen yetiştirme & 1 & $\% 7$ \\
Kaliteli hizmet içi eğitim & 1 & $\% 7$ \\
Ekip ruhu kazandırma & 1 & $\% 7$ \\
Eğitim özelleştirilmeli & 1 & $\% 7$ \\
\hline
\end{tabular}

Eğitimde kaliteyi artırma yolları hakkında öğretmenlere görüşleri sorulduğunda çevre desteği ve öğrenci memnuniyetini önemsediğini dile getiren öğretmenlerimizden biri açıklamasını şu şekilde yapmıştır:

K2: “....Eğitimi kaliteli kılan çıktıların memnuniyet oranlarıdır. Bunlar iç ve dış paydaşlarıdır da diyebiliriz.... Velilerin bilinçlendirilmesi çalışmalarına ağırık verilebilir. Öğrenci merkezli eğitimi ögrenciye teslim eğitime değil de başarı ve edep ölçekli öğrenci yetiştirme gayesinde olunmalıdır. Çevrenin ihtiyaçlarına göre dış paydaşların da eğitime katkı desteklerini sağlayıcı çalışmalar yapılmalıdır. ihtiyaçlara göre eğitim kurumları oluşturulmalı, siyasi iktidara göre okullar oluşturulmamalıdır. Gelişen dünya gerçekleri göz önünde tutularak tüm kesimlerin desteğini almış uzun vadeli planlar yapılmalı ve sık sık siyasi gücün istekleri doğrultusunda değiştirilmemelidir."

Bu durumların yanı sıra var olması gereken sevginin önemine değinen K5 ise fikirlerini şöyle dile getirmiştir:

“... Elbette ki sorunları artıran ekonomik ve sosyal oluşumları da önlemeye çalışmalıyız... Neticede her şey bir bütün, öğretmenin de elinde sihirli bir değnek yok... Ülkede yaşanılanların, ailede yaşanılanların bir yansıması eğitim dediğimiz şeyde... Öncelikle adil bir eşitlik, her eşitlik adil olmuyor maalesef... Çalışanın yolunu açmak, teşvik etmek, insana değer vermek gerisi zaten gelir..."

Katıımcı öğretmenler eğitimde kaliteyi artırma yolu olarak \% 50 oranla nitelikli aile eğitimini işaret etmişlerdir. Benzer oranlarda Veli-öğretmen-öğrenci ilişkisini güçlendirme de öğretmenlerin dikkat çektikleri hususlardan olmuştur. Öğretmenlerimiz eğitim sürecinde en fazla iletişimsizlikten yakınmaktadırlar. Bulgulara göre bu kopukluk gerek veli- öğrenci gerekse 
öğretmen- idare arasında olsun eğitimi sekteye uğratmaktadır. Kaliteli eğitim için en önemli olan unsurlardan biri yapıcı olmak ve öğrenciyi bu işin yararına inandırabilmektir. Yapılan işin veli ve ya idare tarafından da desteklenmesi gerekmektedir. Katılımcı öğretmenlerin görüşlerine göre çevreden destek görmeyen öğretmenin tek başına bu sorumluluğu devam ettirmesinin mümkün olmadığı söylenebilir.

\section{SONUÇ, TARTIŞMA VE ÖNERILER}

Eğitimde kalite yarınlarımızı oluşturan çocuklarımızın gelişimi için yemek içmek gibi bir zorunluluktur. Kalite birçok kurum tarafından sıfır hataya yaklaşmak için uygulanır. Eğitimin ürünü insan olduğundan sıfır hatadan bahsetmek mümkün değildir. Eğitim bireyde istendik yönde davranış değişikliği yapma sanatı; kaliteli eğitim ise bu değişikleri öğrencinin bile isteye, zevkle yaşamış olmasıdır (Demirel, 1999; Glasser,1999).

Araştırma sonuçlarına göre öğretmenlerimizin büyük çoğunluğu ülkemizde uygulanan toplam kalite yönetimi çalışmalarını kağıt üzerinde yapılan hiçbir geçerliliği olmayan adımlar içeren uygulamalar bütünü olarak görmektedirler. Eğitimde kalite yönetimi uygulamalarının ülke içindeki durumunu inceleyen çalışmalara bakıldığında uygulamaların prosedür olarak görüldüğü bu konuda öğretmen ve yöneticilere herhangi bir eğitim verilmediği tespit edilmiştir (Göküş, 2007; Özdemir, 2004; Yaşar, 2004).

Öğretmenler eğitime kalite katacak olan noktanın maddi ve fiziki şartlar olduğunu düşünmektedirler. Türkiye, OECD ülkeleri içinde kişi başına düşen gayrisafi yurtiçi hasılası (GSYiH) düşük olan ülkelerdendir. Bu durum öğretmenlerin belirttiği maddi şartlarla ilişkilendirildiğinde başarının yükselmesini etkileyebilmektedir. 2015 Pisa sonuçlarına göre GSYiH ortalamasının OECD ortalamasının üstünde olması başarı ortalamasını yükseltmesi öngörülmektedir. OECD ülkelerinin ortalama puanları ile öğrenci başına yapılan harcama miktarı arasında pozitif bir ilişki olduğu saptanmıştır. Eğitime harcanan paradaki artış ülkelerin ortalama puanlarında artış olacağını göstermektedir. Bunun yanı sıra öğretmenlere göre fiziki imkânsızlığın kaliteyi etkilediği düşüncesi saptanmıştır. Kalitenin bir göstergesi olarak öğrenci başarısı alındığında; Japonya, İtalya, Macaristan ve Meksika gibi OECD öğrenci başarı ortalanmasından yukarıda bulunan ülkelerin eğitim materyali eksiklik indeksinde Türkiye'den çok daha üst sıralarda olduğu görülmektedir. Pisa 2015'e göre materyal eksikliğinin ülkemizden fazla olduğu belirtilen bu ülkelerde başarının çok daha yüksek olması kalite için fiziki şartların ön sıralarda olmadı̆̆ının göstergesidir ( OECD, 2012; Pisa, 2015). Katılımcı öğretmenler eğitim için yapılan harcamaları az bulurken öğretmen adayları da öğretmen eğitimi için yapılan harcamaları az bulmaktadırlar (Şahan,2016). Genel olarak düşünüldüğünde eğitimin temel taşı olan öğretmenlerin yetiştirilmesinde ve hizmetinde yeterli bütçe sağlanmadığı söylenebilir.

Sarı, Ötünç ve Erceylan (2007) lise öğrencileriyle yaptıkları çalışmalarında öğrenci memnuniyeti ile maddiyat arasında doğrusal ilişki olduğunu tespit etmişlerdir. Öğrencilerin yaşam kalitesi eğitimdeki kalite ile ilişki olduğundan onların okulu tatmin edici bir yer olarak görmeleri önemlidir. Maddi imkânsızlıklar katılımcı öğretmenlerin de belirttiği gibi öğrencilerin sosyo-kültürel etkinliklerini ve dolayısıyla yaşam kalitelerini düşürmektedir.

Araştırma sonuçlarına göre eğitimde kalite artırmanın yolları arasında yönetim anlayışında yapılması gereken değişikliklerden de söz edilmiştir. Öğretmenlerin dile getirdiği katılımlı yönetim Glasser tarafından (1999) liderce yönetim olarak tanımlanmıştır. Kaliteye doğru ilerleyebilmek için geleneksel yönetim anlayışını yani patronca yönetimi liderce yönetimle değiştirmek gerekmektedir. Ermiş (2016) yönetici ve öğretmenlerle yaptığı çalışmasında okul ortamında müdürlerin öğretmenlere oranla daha fazla "biz" olma kavramına vurgu yaptıklarını belirtmiştir. Aynı çalışma uzun süredir çalışan öğretmenlerin okullarındaki kaliteden daha memnun olduklarını tespit etmiştir. Katılımcı öğretmenlerin bahsettiği liderce yönetim şekli 
Ermiş'in (2016) çalışmasına göre daha çok yöneticilerce vurgulanmıştır. Nicel olarak yürütülen araştırma, nitel olarak derinlemesine incelenen bu çalışmayla zıt bulgular elde etmiştir. Bu durumun müdürlerce daha çok dile getirilmesi uygulamada liderce yönetim anlayışını artırmamaktadır. Sonuç olarak kişilerin kendine dair söylediklerinden çok etrafta onu gözlemleyenlerin söylemlerinin incelenmesi önerilebilir.

Liderce yönetim hususları ele alındığında, lider öğretmenin görevi, öğrencileri olumlu yönlendirmek ve sınıfta nasıl daha iyi bir öğrenme ortamı yaratılabileceğine ilişkin onların görüşlerini anlamak ve katkılarını teşvik etmektir. Katılımcıların kaliteli öğretmen özelliklerine verdikleri yanıtlar da bu yönetim şeklini doğrular niteliktedir. Liderce yönetim biçimini eğitimle bir sanayi kurumunda uygulanması arasında fark vardır. Eğitimde lider olan öğretmen öğrencinin kalite dünyasına girmek zorundadır. Kalite dünyası; kişi için önemli ve kaliteli gördüğü simgeleri attığı zihinsel kısımdır. Eğer öğretmen bu dünyada kendine ait bir kalite imgesi oluşturamazsa öğrenci bu iş için gönüllü ve istekli olmaz. Bu durumda da kaliteli eğitimden bahsetmek söz konusu olamaz. İşte bu noktada araştırma bulgularında saptanan öğretmen özelliklerinden sabır ve sevginin kalite simgesi oluşturmayla bağlantısı ortaya koyulabilmektedir. Yapılan araştırmalar öğretmenin taşıması gereken kişisel özellikler konusunda çalışma ile paralel bulgulara sahiptir. Şahan (2016) eğitim fakültesi öğrencileriyle yaptığı çalışmasında öğretmenlerin çocuk sevgi ve değerini bilen kişiler olması gerektiğini öğretmen adaylarının dilinden aktarmıştır.

Kaliteli bir okul ortamı için tüm paydaşların işe dâhil olması gerekmektedir. Bu nedenle öğrenci velilerine de önemli görevler düşmektedir. Yapılan bu çalışmada öğretmenler velilerin yeterince sorumluluk almadıklarını belirtmektedirler. Ülkemizde ailelerin eğitime katılım düzeylerinin istenilen düzeyde olmadığı yapılan diğer çalışmalarca da tespit edilmiştir (Gültekin ve Anagün, 2006). Yapılan çalışmalar göstermektedir ki aile desteğinin artması öğrenci tutum ve akademik başarısında artışı sağlamaktadır (Çelenk, 2002; Demirel, 2002, Keçeli-Kaysılı, 2008). Aynı zamanda velilerin ve öğretmenlerin okulların karar alma sürecine katılmaları demokratik bir okul ortamı sağlayıp kaliteyi artırmaktadır (Şişman, 2010).

Glasser'e göre (1999) Kaliteli bir okulda; üretkenlik dıştan gelen ölçütlerle değerlendirilmez, her öğrencinin gelişimi kayıt altına alınır, zorunlu ödevler azaltılır ve sınıf çalışmalarına ağırlık verilir. Ders programları öğrencilerin kalite dünyasına hizmet etmelidir. Verilen notlar başarısızlığı değil başarıyı temsil eder ve en önemlisi kaliteli okul kalite odaklı öğretmen ve yönetici ister. Çalışma boyunca yöneltilen sorulara kalite için değerlendirme konusunda fikirlere nadir rastlanmaktadır. Süreç değerlendirmeden bahsetmeyen öğretmenlerimiz sonuç olarak değerlendirmeye vurgu yapmış ve bu değerlendirme yaşanan adaletsizliklerden bahsetmişlerdir. Bir okulun kaliteli olması için eğitim çıktısı olan öğrencilerin hangi okullara yerleştiğinin öneminden ve okulu kaliteli kılanın fiziki imkânları olduğundan söz edilmiştir. Okulda olması gereken sosyal ve ekonomik projelere hiç değinilmemiş sadece bir öğretmen tarafından sosyo- kültürel faaliyetlerin önemi vurgulanmıştır.

Sonuç olarak genel bir bakış ile öğretmenler, öğretmen seçiminde yeterli düzeyde ayırt edici olunmadığını, öğretmen eğitiminde saha için gerekli tecrübenin öğretmen adayına kazandırılamadığını belirtmektedirler. Kaliteli eğitim için öğretmenin mesleğini ve öğrencilerini sevmesi sosyal ve sabırlı bir rehber olması gerektiğini vurgulamaktadırlar. Kaliteli okul için fiziki ve mali şartların iyileştirilmesi, kaliteli eğitim için de velilerin bilinçlendirilmesi gerektiğini düşünmektedirler. Çalışma grubundaki öğretmenlerin çoğunluğu Türkiye' de eğitimde uygulanan toplam kalite yönetimi uygulamalarının kâğıt üzerinde yapıldığını ve bu tarz uygulamaların herhangi bir fayda sağlamayacağına inandıklarını dile getirmişlerdir.

Çalışma sonuçlarına göre; eğitimde kalite oluşturma işine öğretmen seçme politikalarında değişiklik yapılarak başlanması önerilebilir. Daha sonra öğretmen yetiştirmede 
uygulama alanları açılarak adayların sahaya uyumu kolaylaştırılabilir. Okul yöneticilerine toplam kaliteye dair verilen seminerler yerine onların dâhil edileceği projelerle bu işe önce yöneticilerin inanması sağlanabilir. Yararına inandığı kalite uygulamalarını okulunda başarıyla uygulayan yönetici ile öğretmenlerin birlikte kaliteyi yükseltmeleri daha kolay olabilir. Okulda yaşanan bu kalite hareketliliği velileri de, somut şeyler görmeleri ile birlikte, işe dâhil edebilir. Çevresindeki profesyonelleşen öğretmen ve yöneticiler ve ilgili ebeveynlerle öğrenci de bu işin yararına inanabilir ve değişimi kendi hayatı içine dâhil edebilir. Çalışma sonuçlarına göre kalite yönetimi planlayıcılarına okullarda daha gerçekçi uygulama örneklerinin tanıtılması önerilebilir. Eğitim kalitesinin paydaşları ve yapabilecekleri uygulamalı olarak kendilerine aktarılabilir. İyi uygulamaların tanıtımı yaygınlaştırılarak gönüllü olan paydaşlara teşvikler ayrılması önerilebilir.

\section{KAYNAKLAR}

Akyüz, Y. (2003). “Osmanlıdan günümüze öğretmen istihdam ilke ve politikalarına eleştirel bir bakış." Öğretmen Yetiştirme ve İstihdamı Sempozyumu. Ankara: Eğitim-Sen Yayınları. 165188.

Atanur- Başkan, G., Aydın, A., Madden, T. (2006). “Türkiye'deki öğretmen yetiştirme sistemine karşılaştırmalı bir bakış."C..̈̈. Sosyal Bilimler Enstitüsü Dergisi, Cilt 15, Sayı 1, s.35-42.

Büyükkaragöz, S. ve diğ. (1998). Öğretmenlik mesleğine giriş (eğitimin temelleri), Konya:Mikro Yayınları: No.07., s.16.

Creswell, J. W. (2007). Research design: Qualitative, quantitative, and mixed methods approaches(2nd ed.). Thousand Oaks, CA: Sage.

Çelenk, S. (2002). “ilkokuma ve yazma öğretiminde karşılaşılan sorunlara ilişkin öğretmen görüşleri" ilköğretim-Online, 1 (2) s.40-47.

Demirel, Ö. (1999). Öğretme sanatı. Ankara: Pegem Yayınları.

Demirel, Ö. (2002). Türkçe öğretimi. Ankara: PeGemA Yayıncılık.

Ekinci, A., \& Öter, Ö. M. (2010). Finlandiya'da eğitim ve öğretmen yetiştirme sistemi(çalışma ziyareti raporu). http://duabpo.dicle.edu.tr/oygem/dosya/Finlandiya_Raporu.pdf_Erişim Tarihi: 22.01.2016)

Ermiş, M. (2016). ISO 9001:2008 Kalite yönetim sistemi uygulamalarının eğitim kurumları kalitesine etkisi. Yeditepe Üniversitesi Eğitim Bilimleri Enstitüsü. (Yayınlanmamış Yüksek Lisans Tezi). İstanbul.

Glasser, W. (2000). Kaliteli eğitimde öğretmen. Çev. U. Kaplan, Beyaz Yayınları, İstanbul.

Glasser, W. (1999). Okulda kaliteli eğitim. Beyaz Yayınları, İstanbul.

Glasser, W. (1999). Başarısızlığın Olmadığı Okul. Çev. Teksöz, K. Beyaz Yayınları, İstanbul.

Göküş, E. (2007). "Kaliteli Okul" kavramının öğretmenler ve yöneticiler tarafından algılanması (Mersin ili, Erdemli illçesi örneği). Gazi Üniversitesi Eğitim Bilimleri Enstitüsü. (Yayınlanmamış Yüksek Lisans Tezi). Ankara.

Gültekin, M., \& Şengül, S. A. (2006). Avrupa birliğinin eğitimde kaliteyi belirleyici alan ve göstergeleri açısından Türk eğitim sisteminin durumu. Anadolu Üniversitesi Sosyal Bilimler Dergisi, Cilt 06, Sayı 2, 145-170.

Kaufman, R. ve Zahn, D. (1993). Quality management plus. London: Sage Publication 
Keçeli-Kaysılı, B. (2008). Akademik başarının arttırılmasında aile katılımı. Ankara Üniversitesi Eğitim Bilimleri Fakültesi Özel Eğitim Dergisi, 9(01), 069-083.

Miles, M. B., \& Huberman, A. M. (1994). Qualitative data analysis: An expanded sourcebook. Sage.

MEB. (2008). Sınıf Öğretmenliği Alan Yeterlikleri. Web: http://otmg.meb.gov.tr/alansinif.html (Erişim Tarihi: 15.01.2017)

Pisa (2015). Ulusal rapor. Web: http://pisa.meb.gov.tr/wpcontent/uploads/2016/12/PISA2015_Ulusal_Rapor1.pdf (Erişim Tarihi: 10.12.2016)

OECD (Organısatıon for Economıc Cooperatıon and Development) (2012) What Makes Schools Successful? Resources, Policies and Practices (Volume IV) Web:http://www.oecd.org/pisa/keyfindings/pisa-2012-results-volume-iv.htm adresinden (Erişim Tarihi: 11.03.2015)

Özdemir, S. M. (2004). Öğretim sürecinde toplam kalite ilkelerinin uygulanmasının öğrenci tutumlarına ve başarısına etkisi. (Yayımlanmamış Doktora Tezi). Ankara: Gazi Üniversitesi Eğitim Bilimleri Enstitüsü.

Sarı, M., Ötünç, E., \& Erceylan, H. (2007). Liselerde okul yaşam kalitesi: Adana ili örneği. Kuram ve uygulamada eğitim yönetimi, 50(50), 297-320.

Seferoğlu, S. S. (2004). Öğretmen yeterlikleri ve mesleki gelişim. Bilim ve Aklın Aydınlığında Eğitim, 58, 40-45.

Şahan, G. (2016). Analysis of the problems encountered in education of teachers and solution recommendations in accordance with the opinions of faculty of education students. International Journal of Environmental and Science Education, 11(5), 1055-1064.

Şahin, A. E. (2009). Eğitim fakültesinde hizmet kalitesinin eğitim fakültesi öğrenci memnuniyet ölçeği (ef-ömö) ile değerlendirilmesi. Hacettepe Üniversitesi Eğitim Fakültesi Dergisi, 37(37).

Şen, H. Ş., \& Erişen, Y. (2002). Öğretmen yetiştiren kurumlarda öğretim elemanlarının etkili öğretmenlik özellikleri. GÜ Gazi Eğitim Fakültesi Dergisi,22(1), 99-116.

Şimşek, H. (2007). Toplam kalite yönetimi: kuramlar, ilkeler, uygulamalar. Ankara: Seçkin.

Şişman, M. (2010). Türk eğitim sistemi ve okul yönetimi. Ankara: PegemA.

UNESCO. (2001). Teachers for Tomorrow's Schools. Paris: UNESCO Publishing Web : http://www.oecd.org/education/school/1840205.pdf (Erişim Tarihi: 10.02.2015)

Yaşar, G. (2004). ilköğretim okullarında toplam kalite yönetimi uygulaması (durum/örnek olay Çalışması). (Yayınlanmamış Yüksek Lisans Tezi). Bolu: Abant İzzet Baysal Üniversitesi Sosyal Bilimler Enstitüsü.

Yıldırım, A. ve Şimşek, H. (2016). Sosyal bilimlerde nitel araştırma yöntemleri, Seçkin Yayınevi, Ankara. 


\section{SUMMARY}

Quality is applied by many organizations to approach zero defect. It is not possible to talk about zero mistakes on education because of the training is human. The education is a art of making changes in the individual; and quality education is the experience of those students who have experienced these changes with pleasure (Demirel, 1999; Glasser, 1999).

This study was conducted to determine teachers' views on quality in education. It is aimed to shed light on areas where lack of with the solution suggestion of teachers, internal stakeholders work to increase quality. The study aimed to answer the following questions in the research: What are the opinions of teachers about the quality of teacher selection and educating; quality teachers; quality school?

The case study was used as a qualitative research type that allows in-depth research to reach the target points in the study. It was attempted to define themes with a case study in which a case was examined in depth within a limited time frame (Creswell, 2007).

In the first semester of 2015-2016 academic year, 14 teachers identified by snowball sampling constitute the study group of this research. In the snowball sampling method, the process continues with reaching the data sources that the individuals who are thought to be able to collect related data can reach and recommended by those people. The data that accumulates in this way reminds me of the cartogram. The researcher may terminate when the process has reached a sufficient level or when the suggested names start to coincide (Yıldırım \& Şimşek, 2016). 21\% of the participants consisted of male teachers and $79 \%$ female teachers. The professional experience of participating teachers constitutes a majority between $64 \%$ and 6 to 15 years. The fact that the teachers are the people in the Total Quality Management studies in the schools and the fact that they were interviewed by one person from each school differentiated branch distributions. $7 \%$ of the schools are industrial vocational high school, $7 \%$ are Anatolian high school, $7 \%$ are religious vocational School, $7 \%$ are kindergarten, $35 \%$ are secondary school and $35 \%$ are primary school. The semi-structured interview form used as a data gathering tool has been prepared by researchers with questions about subproblems. Pilot practice was used to determine alternative questions. The pre-negotiation semi-structured interview form was based on two expert opinions and the coverage was validated and finalized. The semi-structured interview form consists of 14 open ended questions. In the analysis of the data, content analysis method was used. The main goal in content analysis is to reach the concepts and associations that can explain the collected data. For this purpose, the collected data must first be conceptualized, then organized in a logical way according to the emerging concepts and the themes describing the data should be determined (Yıldırım and Şimşek, 2016). For each code, a percentile account was made on the total number of participants to tabulate. During the coding of the data obtained from the interviews, a specialist external auditor was assisted in the field. The results obtained by mutual exchange of views with the external auditor were assessed together progressively.

According to the results of the research, the vast majority of our teachers view the total quality management practices applied on paper in our country which have no validity. Teachers think that the pecuniary and physical conditions are the point that will add educational quality. Participant teachers find very low spending for teacher education like teacher candidates from Şahan's study (2016). It can be said that the teachers, who are the cornerstone of education, have not provided adequate budget for their education and service. According to the results of the research, the ways to improve quality in education have been mentioned about the changes in management understanding. The participatory management expressed by the teachers is defined by Glasser (1999) as leadership management. In order to be able to move towards quality, it is necessary to change the traditional management mentality, that is, the boss management to the leadership management.

According to the study results; it may be advisable to start by making changes in teacher selection policies to quality building in education. Afterwards, the application areas can be opened with teacher education and it is possible to facilitate adaptation of candidates to the field. Instead of the seminars given to the school administrators regarding the total quality, the managers will be able to believe this project before they can be involved. 